\title{
GRATIFIKASI DALAM PERSPEKTIF HUKUM POSITIF DI INDONESIA DAN SOLUSINYA MENURUT ISLAM
}

\section{Gratification in the Perspective of Positive Law in Indonesia and the Solution According to Islam}

\begin{abstract}
Fazzan $^{1}$
Abdul Karim Ali²

ABSTRACT

The codification of rules regulating gratification is a novelty within society and is perceived to collide with the culture of giving in the Islamic ethos of Indonesia. This study aims to explore the meaning of gratification from the positive perspective of law in Indonesia and the boundaries of gratification. This study uses the normative method which analyzes positive law in Indonesia regulating gratification. The results show that gratification from the perspective of positive law has broad meaning including tributes for civil and government employees. According to Indonesian law, gratification may either be positive or negative. Gratification is a gift from the pure intention of the giver to a civil
\end{abstract}

\footnotetext{
1 Ph.D Candidate, Department of Figh and Usul, Academy of Islamic Studies, University of Malaya, 50603 Kuala Lumpur, fazzan.ma@yahoo.com

2 Associate Professor, Department of Fiqh and Usul, Academy of Islamic Studies, University of Malaya, 50603 Kuala Lumpur, abdkarim@um.edu.my
} 
or government employee without expecting anything in return. On the contrary, forms of gratification which are not allowed include gifts for civil and government employees due to their status of authority or for reasons unrelated to their position. Moreover, the standards set by Islam regarding gratification are by first giving proper salary, registering the property of employees, performing all the Commands of Allah, keeping away from taking other's property, running the "altaftisi"” (the escord) for the Civil Servant and State Apparatus, maximizing punishments, maintaining the supremacy of law, amending and improving the system, strengthening the understanding of law, building a model for leadership, and cultural progression (morally and intellectually).

Keywords: gratification, positive laws perspective, solutions by Islam

\section{PENDAHULUAN}

Gratifikasi mula dikenali oleh masyarakat sejak disahkannya UndangUndang Nombor 20 Tahun 2001 amandemen (pindaan/kemaskini) ke atas Undang-Undang Nombor 31 Tahun 1999 berkenaan Pemberantasan Tindak Pidana Korupsi. Walaupun undang-undang tersebut sudah disahkan sejak 14 tahun lalu, konsep tentang gratifikasi sendiri masih dianggap sebagai sesuatu perkara yang baru bagi masyarakat, dan seringkali dianggap sebagai hal yang bertentangan dengan budaya saling memberi dalam kalangan masyarakat. Ada anggapan bahawa aturan tentang gratifikasi merupakan perkara yang merosakkan budaya khususnya budaya saling memberi dalam kalangan umat Islam termasuk masyarakat Islam di Indonesia.

Selain dianggap bertentangan dengan budaya pemberian yang ada dalam masyarakat Islam di Indonesia, undang-undang gratifikasi juga seringkali dianggap tidak sesuai dengan ajaran agama. Ini kerana budaya saling memberi merupakan perkara yang sangat dianjurkan dalam Islam. Berdasarkan latar belakang di atas, isu ini perlu diberikan penjelasan tentang peraturan gratifikasi di Indonesia, iaitu adakah benar undang-undang yang berlaku di Indonesia melarang semua bentuk gratifikasi yang sudah menjadi kebiasaan dalam kehidupan masyarakat Islam di Indonesia. Untuk itu, dalam kajian ini penulis akan menghuraikan tentang gratifikasi dalam tinjauan undang-undang semasa di Indonesia. Ia meliputi perbincangan mengenai definisi gratifikasi, asas hukum gratifikasi dan unsur-unsur gratifikasi, kes mahkamah mengenai gratifikasi, dan kedudukan gratifikasi dalam perspektif undang-undang semasa Indonesia, serta solusinya menurut Islam. 


\section{DEFINISI GRATIFIKASI}

Dalam kamus Bahasa Indonesia, gratifikasi diertikan sebagai pemberian hadiah wang kepada pegawai di luar gaji yang ditentukan. ${ }^{3}$ Sedangkan dalam kamus Hukum, gratifikasi yang berasal dari Bahasa Belanda, gratificatie, atau bahasa Inggerisnya gratification diertikan sebagai hadiah wang. Berdasarkan kedua definisi tersebut, baik dalam kamus Bahasa Indonesia mahupun kamus Hukum, gratifikasi diertikan sebagai pemberian hadiah dalam bentuk wang. Definisi dalam kedua-dua kamus tersebut bersifat neutral. Ertinya, amalan gratifikasi bukanlah merupakan suatu amalan tercela atau perbuatan yang negatif. Sedangkan objek gratifikasi dalam kamus Bahasa Indonesia jelas ditujukan kepada pegawai, manakala dalam kamus Hukum, objek gratifikasi tidak ditentukan. ${ }^{4}$

Adapun definisi gratifikasi mengikut undang-undang, terdapat pada penjelasan Fasal 12 B ayat 1 Undang-undang Nombor 31 Tahun 1999 juncto (pindaan) Undang-Undang Nombor 20 Tahun 2001, bahawa:

"Yang dimaksudkan dengan "gratifikasi” dalam ayat ini adalah pemberian dalam erti luas, yakni meliputi pemberian wang, barang, rebat (discount), komisyen, pinjaman tanpa bunga, tiket pelancongan, kemudahan penginapan, perjalanan pelancongan, rawatan percuma (gratis), dan kemudahan lain. Gratifikasi tersebut baik yang diterima di dalam negeri maupun di luar negeri dan yang dilakukan dengan menggunakan cara elektronik atau tanpa sarana elektronik. ", 5

Apabila diteliti penjelasan fasal 12 B ayat 1 di atas, kalimat yang termasuk definisi gratifikasi adalah sebatas kalimat pemberian dalam erti luas, sedangkan kalimat setelah itu merupakan bentuk-bentuk gratifikasi. Dari penjelasan fasal $12 \mathrm{~B}$ ayat 1 juga dapat dilihat bahawa pengertian gratifikasi mempunyai makna yang neutral, iaitu tidak terdapat makna tercela atau negatif dari erti kata gratifikasi tersebut. Apabila penjelasan ini dihubungkan dengan rumusan fasal $12 \mathrm{~B}$ dapat difahami bahawa tidak semua gratifikasi itu bertentangan dengan undang-undang, kecuali gratifikasi yang memenuhi kriteria dalam unsur fasal 12 B sahaja.

3 Tanti Yuniar, Kamus Lengkap Bahasa Indonesia (Jakarta: Agung Media Mulia, tt.), 224.

4 Eddy OS Hiareij, 'Memahami Gratifikasi,' Kompas.com, http://nasional.kompas. com/read/2011/06/13/03392292/memahami.gratifikasi, 13 Julai 2011.

5 Fasal 12 B Ayat 1 Undang-undang Nombor 20 Tahun 2001 tentang Pemberantasan Tindak Pidana Korupsi. 
Untuk mengetahui bilakah gratifikasi menjadi kesalahan jenayah, perlu dilihat rumusan Fasal 12 B ayat 1 Undang-Undang Nombor 20 Tahun 2001 tersebut, setiap gratifikasi kepada Pegawai Negeri atau Penyelenggara Negara dianggap pemberian korupsi, apabila berhubungan dengan jawatannya dan yang berlawanan dengan kewajipan atau tugasnya. ${ }^{6}$

Jika dilihat dari rumusan di atas, maka dapat disimpulkan bahawa gratifikasi atau pemberian hadiah akan berubah menjadi suatu perbuatan jenayah korupsi khususnya bagi seseorang Pegawai Negeri atau Penyelenggara Negara sekiranya mereka menerima gratifikasi atau hadiah daripada mana-mana pihak sepanjang pemberian tersebut diberikan berkaitan dengan jawatan ataupun pekerjaannya. Namun apabila pemberian tersebut tidak ada hubungan dengan pekerjaan atau jawatannya serta tidak berlawanan dengan tugasnya, maka pemberian itu masih dalam bentuk gratifikasi yang dibenarkan mengikut undang-undang.

Salah satu kebiasaan dalam masyarakat adalah pemberian sebagai tanda terima kasih atas jasa yang telah diberikan oleh kakitangan, baik dalam bentuk barang atau wang. Hal ini boleh menjadi suatu kebiasaan yang bersifat negatif dan boleh menjadi potensi perbuatan korupsi di kemudian hari. Potensi korupsi inilah yang cuba dicegah melalui peruntukan undang-undang yang sedia ada. Undang-undang tidak melarang amalan gratifikasi atau pemberian hadiah dalam kalangan masyarakat secara umum, tetapi terdapat larangan bagi Pegawai Negeri atau Penyelenggara Negara untuk menerima gratifikasi yang boleh dianggap korupsi.

Terdapat tiga perbezaan di antara amalan gratifikasi dengan amalan korupsi. Pertama, ketegasan hukumnya. Amalan korupsi berupa kerugian kewangan negara, sogokan, penyelewengan dalam jawatan, perbuatan curang, pertentangan kepentingan dalam perolehan tender sudah jelas amalan tersebut adalah illegal. Namun berkaitan dengan amalan gratifikasi, apabila amalan itu terbukti wujud, ia tidak boleh terus dihukum sebagai illegal, bahkan perlu mengambil kira pertimbangan-pertimbangan tertentu. Pertimbangan yang dimaksudkan itu ialah pemberian tersebut dilakukan kerana berkaitan dengan jawatannya yang bertentangan dengan kewajipan atau tugas Pegawai Negeri atau Penyelenggara Negara. Dengan kata lain, gratifikasi pada dasarnya ialah amalan yang mendorong terjadinya perbuatan bertentangan dengan undangundang dari amalan korupsi lain. Kedua, bergantung kepada skop amalannya. Amalan korupsi selain gratifikasi hanya terhad pada jumlah amalan yang sudah ditentukan oleh undang-undang, namun berkenaan dengan amalan gratifikasi

Fasal 12 B Ayat 1 Undang-undang Nombor 20 Tahun 2001 tentang Pemberantasan Tindak Pidana Korupsi. 
sifatnya adalah tidak terhad. Ini kerana pemberian yang dimaksudkan itu ialah pemberian dalam erti kata yang luas. Dengan begitu, bentuk-bentuk amalan yang tidak termasuk dalam jenis amalan yang sudah disebutkan undang-undang boleh dimasukkan ke dalam gratifikasi. Ketiga, dari segi penekanan penilaian. Korupsi selain gratifikasi penekanan penilaiannya diukur berdasarkan institusi atau orang yang diberi kuasa. Iaitu penilaian terhadap adanya jawatan atau kuasa untuk berbuat demikian. Akan tetapi, selain diukur dari sisi institusi atau orang yang diberi kuasa, perlu juga dinilai dari sisi masyarakatnya. Ini kerana terdapat juga faktor masyarakat yang menyokong perbuatan jenayah tersebut sehingga ianya berlaku.

Berdasarkan huraian di atas dapat disimpulkan bahawa gratifikasi yang dibenarkan oleh undang-undang semasa yang berlaku di Indonesia adalah pemberian yang dilakukan dengan niat yang tulus daripada seseorang kepada individu yang lain sebagai "tanda terima kasih" tanpa mengharapkan sebarang balasan. Sedangkan gratifikasi yang dilarang oleh undang-undang adalah penerimaan gratifikasi oleh Pegawai Negeri atau Penyelenggara Negara yang dianggap sebagai perbuatan korupsi apabila pemberian tersebut dilakukan kerana berhubungan dengan kedudukan sebagai petugas negara dan berlawanan dengan kewajipan atau tugasnya.

\section{ASAS HUKUM GRATIFIKASI DAN UNSUR-UNSUR GRATIFIKASI}

Pengaturan tentang gratifikasi diperlukan untuk mencegah terjadinya jenayah korupsi yang dilakukan oleh Pegawai Negeri atau Penyelenggara Negara. Melalui pengaturan ini diharapkan Pegawai Negeri atau Penyelenggara Negara dan masyarakat boleh mengambil langkah-langkah yang sewajarnya, iaitu dengan menolak atau segera melaporkan gratifikasi yang diterimanya. Secara khusus gratifikasi ini diatur dalam Undang-Undang Republik Indonesia Nombor 20 Tahun 2001 tentang Pemberantasan Tindak Pidana Korupsi, iaitu:

Fasal 12 B

a) "Setiap gratifikasi kepada pegawai negeri atau penyelenggara negara dianggap pemberian suap, apabila berhubungan dengan jabatannya dan yang berlawanan dengan kewajiban atau tugasnya, dengan ketentuan sebagai berikut:

i) yang nilainya Rp 10,000,000,00 atau lebih, pembuktian bahwa gratifikasi tersebut bukan merupakan suap dilakukan oleh penerima gratifikasi; 
ii) yang nilainya kurang dari Rp 10,000,000,00 pembuktian bahwa gratifikasi tersebut suap dilakukan oleh penuntut umum."

b) "Pidana bagi pegawai negeri atau penyelenggara negara sebagaimana dimaksud dalam ayat (1) adalah pidana penjara seumur hidup atau pidana penjara paling singkat 4 (empat) tahun dan paling lama 20 (dua puluh) tahun, dan pidana denda paling sedikit $R p$ 200,000,000,00 dan paling banyak $R p$ 1,000,000,000,00”

Fasal $12 \mathrm{C}$

1) "Ketentuan sebagaimana dimaksud dalam Fasal 12 B ayat (1) tidak berlaku, jika penerima melaporkan gratifikasi yang diterimanya kepada Komisi Pemberantasan Tindak Pidana Korupsi."

2) "Penyampaian laporan sebagaimana dimaksud dalam ayat (1) wajib dilakukan oleh penerima gratifikasi paling lambat 30 (tiga puluh) hari kerja terhitung sejak tanggal gratifikasi tersebut diterima."

3) "Komisi Pemberantasan Tindak Pidana Korupsi dalam waktu paling lambat 30 (tiga puluh) hari kerja sejak tanggal menerima laporan wajib menetapkan gratifikasi dapat menjadi milik penerima atau milik negara. (4) Ketentuan mengenai tata cara penyampaian laporan sebagaimana dimaksud dalam ayat (2) dan penentuan status gratifikasi sebagaimana dimaksud dalam ayat (3) diatur dalam Undang-undang tentang Komisi Pemberantasan Tindak Pidana Korupsi." 7

Berdasarkan landasan undang-undang di atas, dapat difahami apabila kesemua unsur yang dinyatakan telah pun dipenuhi, maka gratifikasi dapat diertikan sebagai perbuatan yang melanggar undang-undang. Hukuman terhadap pelaku gratifikasi terdapat pada Fasal 12 B di mana ancaman adalah penjara seumur hidup atau penjara paling singkat empat tahun, dan paling lama 20 tahun. Manakala jumlah denda paling minimum ialah Rp200,000,000,00 dan paling maksimum ialah 1 bilion rupiah. Setiap gratifikasi yang diperolehi Pegawai Negeri atau Penyelenggara Negara adalah dianggap korupsi, namun ketentuan yang sama tidak berlaku apabila penerima melaporkan gratifikasi yang diterimanya kepada Komisi Pemberantasan Korupsi (KPK) yang wajib

7 Fasal 12 B dan 12 C Undang-undang Nombor 20 Tahun 2001 tentang Pemberantasan Tindak Pidana Korupsi. 
dilakukan selewat-lewatnya tiga puluh hari bekerja yang dikira dari tarikh gratifikasi tersebut diterima.

Pihak penerima gratifikasi yang dimaksudkan dalam landasan undangundang ini dibahagikan kepada dua kategori. Pertama, Pegawai Negeri atau Penyelenggara Negara yang menerima hadiah atau janji, padahal diketahui atau patut dianggap hadiah atau janji tersebut diberikan untuk menggerakkan agar melakukan atau tidak melakukan sesuatu dalam jawatannya yang bertentangan dengan kewajipannya. Kedua, Pegawai Negeri atau Penyelenggara Negara yang dengan maksud menguntungkan diri sendiri atau orang lain secara berlawanan dengan undang-undang, atau menyalahgunakan kuasanya dengan memaksa seseorang memberikan sesuatu, membayar, atau menerima bayaran dengan potongan, atau untuk mengerjakan sesuatu bagi dirinya sendiri. ${ }^{8}$

Dari rumusan Fasal 12 B ayat 1 Undang-undang Nombor 20 Tahun 2001 pula, terdapat empat unsur utama yang menyebabkan amalan gratifikasi boleh dianggap sebagai illegal, iaitu Pegawai Negeri atau Penyelenggara Negara, pemberian dan penerimaan gratifikasi (serah terima), berkaitan dengan jawatan, serta berlawanan dengan kewajipan atau tugasnya.

Oleh sebab itu, bagi mengaitkan sesuatu pemberian itu sebagai gratifikasi yang illegal menurut undang-undang, perlu diperhatikan bahawa yang menerima pemberian itu adalah seorang Pegawai Negeri atau Penyelenggara Negara, adanya transaksi pemberian dan penerimaan, kemudian pemberian tersebut berhubungan dengan suatu pekerjaannya sebagai petugas negara, dan berlawanan dengan kewajipan atau tugasnya. Sekiranya tidak ada kaitan dengan kesemua unsur tersebut, dengan kata lain, tidak ada hubungan sebab akibat antara satu unsur dengan lain, maka gratifikasi itu tidak dianggap sebagai suatu perbuatan jenayah yang bertentangan dengan undang-undang.

\section{KES MAHKAMAH MENGENAI GRATIFIKASI}

Sebelum penulis mendedahkan kes-kes amalan gratifikasi yang sudah ada putusan tetap dari mahkamah (inkracht), terlebih dahulu penulis akan memberikan sedikit gambaran umum mengenai data terkini berkenaan

8 Pegawai Negeri sudah jelas adalah Pegawai Negeri Sivil (PNS) baik pusat maupun daerah. Sedangkan Penyelenggara Negara adalah setiap orang yang bertugas dalam kaitan proses kegiatan bernegara, baik secara langsung atau tidak, yang dalam melaksanakan kegiatan pekerjaannya dibiayai oleh bajet negeri atau oleh BUMN. Dapat disimpulkan subjek yang boleh berperanan sebagai penerima gratifikasi ini demikian luas. 
perkembangan pembanterasan gratifikasi, termasuk gratifikasi yang sudah dibuktikan sebagai korupsi, mahupun korupsi jenis lain. Terdapat empat perkara inkracht bermula 27 Februari 2015. Dalam tempoh tahun 2005-2015, jumlah perkara yang diputuskan oleh Pengadilan Negeri adalah sebanyak 141 perkara, Pengadilan Tinggi sebanyak 34 perkara, dan di Mahkamah Agung sebanyak 145 perkara. Jumlah inkracht tersebut adalah sebanyak 287 perkara. Berikut penulis kemukakan data korupsi dalam bentuk jadual:

Jadual 2.2: Data Korupsi Berkekuatan Hukum Tetap Tahun 2005-2015.

\begin{tabular}{lcccccc}
\hline \multicolumn{1}{c}{ Inkracht } & $\mathbf{2 0 0 5}$ & $\mathbf{2 0 0 6}$ & $\mathbf{2 0 0 7}$ & $\mathbf{2 0 0 8}$ & $\mathbf{2 0 0 9}$ & $\mathbf{2 0 1 0}$ \\
\hline Pengadilan Negeri & 3 & 5 & 9 & 9 & 20 & 20 \\
Pengadilan Tinggi & 0 & 3 & 0 & 0 & 2 & 3 \\
Mahkamah Agung & 2 & 9 & 14 & 14 & 17 & 11 \\
Jumlah & $\mathbf{5}$ & $\mathbf{1 7}$ & $\mathbf{2 3}$ & $\mathbf{2 3}$ & $\mathbf{3 9}$ & $\mathbf{3 4}$ \\
\hline \multicolumn{1}{c}{ Inkracht } & $\mathbf{2 0 1 1}$ & $\mathbf{2 0 1 2}$ & $\mathbf{2 0 1 3}$ & $\mathbf{2 0 1 4}$ & $\mathbf{2 0 1 5}$ & Jumlah \\
\hline Pengadilan Negeri & 21 & 8 & 10 & 20 & 16 & 141 \\
Pengadilan Tinggi & 0 & 3 & 10 & 7 & 6 & 34 \\
Mahkamah Agung & 13 & 17 & 20 & 13 & 15 & 145 \\
Jumlah & $\mathbf{3 4}$ & $\mathbf{2 8}$ & $\mathbf{4 0}$ & $\mathbf{4 0}$ & $\mathbf{3 7}$ & $\mathbf{3 2 0}$ \\
\hline Sumber: Portal & Pengetahuan & Anti & Korupsi, & http://acch.kpk.go.id/ \\
inkracht?inheritRedirect=true. & & & & &
\end{tabular}

Sedangkan data terkini tahun 2015 khusus mengenai gratifikasi dan korupsi jenis gratifikasi, dapat penulis jelaskan sebagai berikut:

\section{1) Gratifikasi berdasarkan Status Pemilikan}

Sejak 27 Februari 2015, jumlah gratifikasi yang dilaporkan ke Komisi Pemberantasan Korupsi (KPK), berstatus milik negara sebanyak 17 laporan, milik penerima 6 laporan, sebahagian milik negara 5 laporan, masih dalam proses sebanyak 191 laporan, dan non SK (Surat Keputusan) sebanyak 
59 laporan. Jumlah keseluruhan pelaporan gratifikasi di tahun 2015 adalah sebanyak 278 laporan. ${ }^{9}$

\section{2) Gratifikasi berdasarkan Institusi}

Sejak 27 Februari 2015, pada tahun 2015 tercatat dari lembaga eksekutif 120 laporan, BUMD/BUMN sebanyak 148 laporan, institusi yudikatif sebanyak 6 laporan, lembaga legislatif sebanyak 0 laporan, dan lembaga independen 4 laporan. Jumlah keseluruhan pelaporan gratifikasi pada tahun 2015 adalah sebanyak 278 laporan.

Dari data di atas khusus berkenaan dengan laporan gratifikasi, pada tahun 2015 sahaja berjumlah 278 laporan. Namun perlu diperhatikan bahawa tidak semua laporan tersebut pasti menjadi amalan gratifikasi yang illegal (korupsi). Untuk menentukan dakwaan ke arah gratifikasi illegal perlu adanya pembuktian bahawa gratifikasi yang dilaporkan tersebut terjadi berkaitan dengan pekerjaan dan berlawanan dengan tugas atau kewajipan seorang Pegawai Negeri atau Penyelenggara Negara.

Penulis memberikan satu contoh kes mahkamah berkenaan dengan korupsi yang bukan jenis gratifikasi, sebagai data pembanding kes mahkamah untuk gratifikasi illegal (korupsi). Iaitu kes korupsi berkaitan tender Barang dang Jasa dalam pembelian yang menyebabkan kerugian kewangan negara, dan penggelapan/penyelewengan dalam kedudukannya sebagai Penyelenggara Negara yang dilakukan oleh Abdullah Puteh sebagai Gabenor Provinsi Nanggroe Acheh Darussalam (sekarang Provinsi Acheh) tempoh tahun 20002004. Korupsi berlaku dalam pembelian satu unit pesawat helikopter type MI-2, VIP Cabin versi sivil buatan tahun 2000-2001 dari kilang Mil Moscow Helicopter Plant Rusia. ${ }^{10}$

Dari kes ini, jelas amalan yang dilakukan Abdullah Puteh sebuah jenayah dari sudut undang-undang di Indonesia. Kerana dengan sengaja tertuduh melakukan pengambilan wang negara untuk kepentingan peribadi dengan memanfaatkan kekuasaan yang dimilikinya. Dan perbuatan tersebut menyebabkan kerugian negara. Dalam kes ini jelas tidak ada unsur gratifikasi, kerana jenayah yang dilakukan tertuduh bukan dilandasi oleh keinginan orang

\footnotetext{
9 Penulis tidak diketahui, 'Gratifikasi Berdasarkan Status Kepemilikan,' Anti-Corruption Clearing House (ACCH), http://acch.kpk.go.id/gratifikasiberdasarkan-status-kepemilikan, 6 April 2015.

10 Penulis tidak diketahui, 'Abdullah Puteh,' Anti-Corruption Clearing House (ACCH), http://acch.kpk.go.id/abdullah-puteh, 7 April 2015.
} 
lain untuk memberikan wang kepadanya. Sehingga kes ini dikategorikan sebagai korupsi yang bukan jenis gratifikasi.

Kemudian, penulis akan mendedahkan contoh kes gratifikasi yang sudah disabitkan di mahkamah. Ertinya amalan gratifikasi ini telah dibuktikan positif sebagai korupsi. Penulis akan memberikan contoh kes sebagai penerima gratifikasi mahupun sebagai pemberi gratifikasi:

\section{Kes Angelina Sondakh (Penerima Gratifikasi)}

Angelina Sondakh adalah Anggota DPR-RI 2009-2014 yang telah terlibat sebagai penerima gratifikasi pada tahun 2009-2010. Berdasarkan keputusan No. 1616 K/Pid.Sus/2013, Tgl. 20 November 2013, Mahkamah Agung menjatuhkan hukuman kepadanya berupa jenayah penjara 12 (dua belas) tahun, denda Rp 500,000,000, dan wang pengganti (wang yang diterima) Rp 12.580.000.000, dan US \$2.350.000. ${ }^{11}$

Jumlah wang yang diterima Angie berjumlah Rp 12,58 Bilion dan US \$ $2,035,000$ sebagai bentuk pemberian gratifikasi untuk meloloskan anggaran projek aktiviti/program pendidikan tinggi di Kemendiknas dan program pembangunan sarana dan prasarana di Kemenpora untuk memenuhi permintaan Permai Grup. ${ }^{12}$

\section{Kes Miranda Swaray Goeltom (Pemberi Gratifikasi)}

Miranda Swaray Goeltom bekerja sebagai Deputi Gubernur Senior Bank Indonesia(DGSBI) tahun 2004-2009. Pemberian gratifikasi untuk pemilihannya sebagai DGSBI berlaku sebelum Miranda terpilih sebagai DGSBI. Pada masa itu ada tiga orang calon DGSBI yang akan menjalani proses menguji syarat dan kelayakan (fit and proper test) oleh DPR-RI dalam rangka pemilihan DGSBI, iaitu Miranda Goeltom, Hartadi A Sarwono dan Budi Rochadi. ${ }^{13}$

Sebelum pelaksanaan pemilihan, Miranda pernah gagal dipilih dalam pemilihan Gabenor Bank Indonesia pada tahun 2003, melakukan pertemuan dengan Nunun Nurbaetie, di mana dalam mesyuarat itu beliau meminta Nunun membantu mengusahakan kemenangan Miranda dalam fit and proper

11 Penulis tidak diketahui, 'Angelina Patrica Sondakh,' Anti-Corruption Clearing House (ACCH), http://acch.kpk.go.id/angelina-patricia-pingkan-sondakh, 7 April 2015.

12 Penulis tidak diketahui, 'Angelina Patrica Sondakh.'

13 Penulis tidak diketahui, 'Miranda Saraway Goeltom,' Anti-Corruption Clearing House (ACCH), http://acch.kpk.go.id/miranda-swaray-goeltom, 7 April 2015. 
test Deputi Gubernur Senior BI tahun 2004. Miranda meminta Nunun memperkenalkan teman-teman Nunun yang menjadi ahli Komisi IX DPRRI, bagi tujuan mencari sokongan ke atas pencalonannya. Nunun menyetujui permintaan Miranda, maka mesyuarat pun berlaku. ${ }^{14}$

Sebagai ganjaran dari sokongan tersebut, Miranda melalui kakitangannya terbukti membahagikan cek travel BII (Bank Internasional Indonesia) masingmasing di Komisi IX DPR RI pada waktu berlangsungnya fit and proper test. Duhie Makmun Murod menerima cek BII dengan nilai keseluruhannya kurang lebih Rp 9,8 Bilion, Endin AJ Soefihara menerima cek travel BII dengan keseluruhannya bernilai Rp 1,25 Bilion, manakala Hamka Yandhu menerima cek travel BII yang bernilai Rp 7,8 Bilion. Cek-cek tersebut diambil untuk tiga penerima di atas, juga diagihkan kepada rakan-rakannya sesama anggota komisi IX dari fraksi parti masing-masing. ${ }^{15}$

Dengan demikian, Miranda Goeltom yang dibantu oleh Nunun Nurbaetie, telah memberi gratifikasi berupa cek travel BII bernilai Rp 20,85 Bilion, yang merupakan sebahagian dari jumlah keseluruhan 480 keping cek travel BII bernilai Rp 24 Bilion kepada anggota DPR-RI. Akibat daripada perbuatannya, berdasarkan keputusan Mahkamah Agung No. 545 K/Pid.Sus/2013, bertarikh 25 April 2013, Miranda Swaray Goeltom dihukum penjara selama 3 (tiga) tahun penjara dan denda sebanyak Rp 100,000,000.

Kes mahkamah berkaitan dengan Angelina Sondakh dan Miranda Swaray Goeltom jelas bahawa jenayah yang berlaku didasari oleh adanya keinginan dari masyarakat untuk memberikan wang kepada Penyelenggara Negara. Kemudian apabila diselidiki ternyata terbukti bahawa dalam amalan tersebut berlakunya tindakan yang dilakukan oleh Angelina Sondakh menyalahi dari kewajiban dan tugasnya sebagai Anggota DPR-RI dan pemberian yang ia terima berkaitan dengan pekerjaannya sebagai ahli parlimen. Sedangkan gratifikasi yang diberikan oleh Miranda Swaray juga didasari kerana jawatan yang dimiliki oleh penerima gratifikasi sebagai ahli parlimen, dan akibat dari pemberiannya memerlukan ahli parlimen melakukan suatu amalan yang bertentangan dengan tugas dan tanggungjawabnya dalam melakukan uji terhadap calon Deputi Gubernur Senior Bank Indonesia yang seharusnya tidak boleh memihak. Mereka perlu melakukan uji secara neutral dengan meluluskan calon berdasarkan integriti bukan berdasarkan pemberian gratifikasi berupa cek travel.

14 Penulis tidak diketahui, 'Miranda Saraway Goeltom.'

15 Penulis tidak diketahui, 'Miranda Saraway Goeltom.' 
Dari satu contoh kes tentang korupsi penyelewengan dalam jabatan, perbuatan curang, pertentangan kepentingan dalam pengadaan barang (tender) pembelian helikopter jelas berbeza kronologi kejadiannya dengan tiga kes korupsi dalam bentuk gratifikasi setelahnya. Perbezaannya adalah dengan terbuktinya ada pengambilan wang negara untuk kepentingan peribadi yang kemudiannya menjadi bukti telah berbuat korupsi.

Namun dalam kes gratifikasi, apabila terbukti menerima gratifikasi, sebagai contoh kes Angelina Sondakh perlu dibuktikan terlebih dahulu bahawa penerimaan gratifikasi tersebut benar-benar berkaitan dengan jabatan dan berlawanan dengan tugas. Dalam kes Miranda Swaray Goeltom, perlu dikesan terlebih dahulu bahawa pemberian tersebut betul-betul berkaitan dengan jawatan penerima, bertentangan dengan tugas penerima dan berkaitan dengan fit and proper test Miranda Swaray Goeltom sebagai calon Deputi Gubernur Senior Bank Indonesia.

\section{KEDUDUKAN GRATIFIKASI BERDASARKAN UNDANG-UNDANG SEMASA DI INDONESIA}

Dalam Undang-undang Nombor 20 Tahun 2001 tentang Pemberantasan Tindak Pidana Korupsi yang merupakan pindaan terhadap Undang-undang Nombor 31 Tahun 1999 tentang Pemberantasan Tindak Pidana Korupsi, ada 30 bentuk/ jenis tindak jenayah korupsi yang dijabarkan sebagai berikut, iaitu:
“ 1.) Menyuap pegawai negeri adalah korupsi; 2.) memberi hadiah kepada pegawai negeri karena jabatannya adalah korupsi; 3.) pegawai negeri menerima suap; 4.) pegawai negeri menerima hadiah yang berhubungan dengan jabatannya; 5.) menyuap hakim; 6.) menyuap advokat; 7.) hakim dan advokat menerima suap; 8.) hakim menerima suap; 9.) advokat menerima suap; 10.) pegawai negeri menggelapkan uang atau membiarkan penggelapan; 11.) pegawai negeri memalsukan buku untuk pemeriksaan administrasi; 12.) pegawai negeri merusakkan alat bukti; 13.) pegawai negeri membiarkan orang lain merusakkan bukti; 14.) pegawai negeri membantu orang lain merusakkan alat bukti; 15.) pegawai negeri memeras; 16.) pegawai negeri memeras pegawai negeri yang lain; 17.) pemborong membuat curang; 18.) pengawas proyek membiarkan perbuatan curang; 19.) rekanan TNI/Polri berbuat curang; 20.) pengawas rekanan TNI/Polri berbuat curang; 21.) penerima barang TNI/Polri membiarkan perbuatan curang; 22.) pegawai negeri menyerobot 
tanah negara sehingga merugikan orang lain; 23.) pegawai negeri turut serta dalam pengadaan yang diurusnya; 24.) pegawai negeri menerima gratifikasi dan tidak lapor KPK (Komisi Pemberantasan Korupsi) adalah korupsi; 25.) merintangi proses pemeriksaan perkara korupsi; 26.) tersangka tidak memberikan keterangan mengenai kekayaan; 27.) bankyang tidak memberikan keterangan rekening tersangka; 28.) saksi atau ahli yang tidak memberikan keterangan atau memberikan keterangan palsu; 29.) orang yang memegang rahasia jabatan tidak memberikan keterangan atau memberikan keterangan palsu; 30.) dan saksi yang membuka identitas pelapor." 16

30 jenis jenayah korupsi tersebut pada dasarnya dapat dikumpulkan menjadi tujuh, iaitu, kerugian kewangan negara, suap-menyuap (sogokan), penggelapan/penyelewengan dalam jawatan, pemerasan (peras ugut), perbuatan curang, pertentangan kepentingan dalam pengadaan barang (tender), dan gratifikasi. Berkenaan dengan gratifikasi, Undang-undang Nombor 20 Tahun 2001 tentang Pemberantasan Tindak Pidana Korupsi yang merupakan pindaan terhadap Undang-undang Nombor 31 Tahun 1999 untuk pertama kalinya istilah gratifikasi digunakan dalam perundangan di Indonesia, yang dinyatakan dalam Fasal 12 B.

Dalaman Fasal 12 B ini, perbuatan menerima gratifikasi oleh Pegawai Negeri atau Penyelenggara Negara yang dianggap sebagai perbuatan korupsi apabila pemberian tersebut dilakukan kerana berhubung dengan jawatannya dan berlawanan dengan kewajiban atau tugasnya. ${ }^{17}$ Terbentuknya peraturan tentang gratifikasi ini merupakan bentuk kesedaran bahawa gratifikasi dapat mempunyai kesan yang negatif dan boleh disalahgunakan, khususnya dalam rangka penganjuran perkhidmatan awam, sehingga unsur ini diatur dalam perundang-undangan mengenai korupsi. Diharapkan jika budaya pemberian dan penerimaan gratifikasi kepada/oleh Pegawai Negeri dan Penyelenggara Negara dapat dihentikan, maka jenayah korupsi dapat dikurangkan bahkan dihilangkan.

16 Fasal 2, 3, 13, dan 14 Undang-undang Nombor 31 Tahun 1999 tentang Pemberantasan Tindak Pidana Korupsi. Fasal 5, 6, 7, 8, 9, 10, 11, dan 12, Undangundang Nombor 20 Tahun 2001 tentang Pemberantasan Tindak Pidana Korupsi. Penulis tidak diketahui, "Tentang ACCH", Anti-Corruption Clearing House (ACCH), http://acch.kpk.go.id/tentang-acch, 6 April 2015.

17 Fasal 2 Undang-undang Nombor 28 Tahun 1999 Tentang Penyelenggara Negara Yang Bersih dan Bebas dari Korupsi, Kolusi, dan Nepotisme. Lihat juga, Doni Muhardiansyah et al., Buku Saku Memahami Gratifikasi (Jakarta: Komisi Pemberantasan Korupsi Republik Indonesia, 2010), 11. 
Yang dimaksud dengan Pegawai Negeri dan Penyelenggara Negara dalam Undang-undang iaitu:

"Pegawai Negeri berdasarkan Pasal 1 ayat 2 Undang-undang Nomor 31 Tahun 1999 sebagaimana telah diubah dengan Undang-undang Nomor 20 Tahun 2001, meliputi:

1.) Pegawai pada: $M A, M K$

2.) Pegawai pada Kementerian/Departemen \& Lembaga Pemerintah Non Departemen

3.) Pegawai pada Kejagung

4.) Pegawai pada Bank Indonesia

5.) Pimpinan dan pegawai pada sekretariat $M P R / D P R /$ DPD/DPRD Provinsi/Dati II

6.) Pegawai dan perguruan tinggi

7.) Pegawai pada komisi atau badan yang dibentuk berdasarkan Undang-undang, Keppres maupun PP

8.) Pimpinan dan pegawai pada Sekretariat Presiden, Sekretariat Wakil Presiden, Sekretariat Kabinet dan Sekretariat Militer

9.) Pegawai pada BUMN dan BUMD

10.) Pegawai pada Badan Peradilan

11.) Anggota TNI dan POLRI serta Pegawai Sipil di lingkungan TNI dan POLRI

12.) Pimpinan dan pegawai di lingkungan Pemda Dati I dan Dati II.

Penyelenggara Negara berdasarkan Pasal 2 Undangundang Nomor 28 Tahun 1999 Tentang Penyelenggara Negara Yang Bersih dan Bebas dari Korupsi, Kolusi, dan Nepotisme, meliputi:

1.) Pejabat Negara pada Lembaga Tertinggi Negara

2.) Pejabat Negara pada Lembaga Tinggi Negara

3.) Menteri

4.) Gubernur

5.) Hakim

6.) Pejabat negara yang lain sesuai dengan ketentuan peraturan perundang-undangan yang berlaku;

a. Duta Besar

b. Wakil Gubenur

c. Bupati/Walikota 
7.) Pejabat lain yang memiliki fungsi strategis dalam kaitannya dengan Penyelenggaraan Negara sesuai dengan ketentuan peraturan perundang-undangan yang berlaku:

a. Direksi, Komisaris, Pejabat Struktural pada BUMN dan BUMD

b. Pimpinan BI dan Pimpinan Badan Penyehatan Perbankan Nasional

c. Pimpinan Perguruan Tinggi Negeri

d. Pejabat Eselon Satu dan pejabat lain yang disamakan pada lingkungan sipil, militer, dan kepolisian negara RI

e. Jaksa

f. Penyidik

g. Panitera Pengadilan

h. $\quad$ Pimpinan dan Bendahara Proyek. ${ }^{18}$

Termasuk dalam pejabat negara yang diamanahkan undang-undang berkaitan dengan Penyelenggara Negara tersebut ialah Presiden Republik Indonesia, anggota Majelis Permusyawaratan Rakyat (MPR) dan sebagainya. Hal ini sebagaimana yang dinyatakan dalam penjelasan Undang-undang Nombor 5 Tahun 2014 tentang Aparatur Sipil Negara. ${ }^{19}$

Berdasarkan realiti dan huraian di atas, jelas pelaksanaan penguatkuasaan peraturan gratifikasi banyak menghadapi halangan kerana kebanyakan masyarakat Indonesia pada umumnya masih menganggap bahawa memberi hadiah (gratifikasi) merupakan hal yang lumrah. Secara sosiologis, hadiah adalah sesuatu yang bukan saja lumrah tetapi juga berperanan sangat penting dalam mengeratkan 'perpaduan sosial' dalam sesebuah masyarakat.

\section{GRATIFIKASI DI INDONESIA MENURUT ISLAM}

Pada dasarnya gratifikasi merupakan pemberian yang dibenarkan dalam Islam. Malahan Islam menganjurkan memberi gratifikasi kerana dengannya akan

18 Fasal 1 ayat 2 Undang-undang Nombor 20 Tahun 2001 pindaan Undang-undang Nombor 31 Tahun 1999 tentang Pemberantasan Tindak Pidana Korupsi. Pasal 2 Undang-undang Nombor 28 Tahun 1999 tentang Penyelenggara Negara Yang Bersih dan Bebas dari Korupsi, Kolusi, dan Nepotisme. Doni Muhardiansyah et. al., Buku Saku, 11.

19 Undang-undang Nombor 5 Tahun 2014 tentang Aparatur Sipil Negara. 
tercipta rasa kasih sayang di antara sesama manusia. Pemberian gratifikasi dapat melahirkan rasa kasih sayang berdasarkan pemberian yang dilakukan berlandaskan hati nurani yang tulus dan ikhlas, dan semata-mata hanya mengharap redha Allah SWT. Akan tetapi dalam realiti dan perkembangannya, gratifikasi kadang-kala dijadikan sebagai alat untuk mencapai tujuan-tujuan tertentu sebagai media untuk mendapatkan keselamatan dan keuntungan. Di antaranya ialah gratifikasi yang diberikan untuk pihak berkuasa atau pegawai kerajaan.

Berdasarkan penjelasan tentang gratifikasi menurut undang-undang semasa di Indonesia, dimana gratifikasi pemberian dalam arti luas yang mana penerimanya adalah Penyelenggara Negara atau Pegawai Negeri Sivil maka gratifikasi dalam pandangan syara' dapat diertikan sebagai hadiah kepada petugas negara atau rishwah. Hadiah kepada petugas negara dan rishwah, kedua amalan tersebut dilarang dalam Islam berdasarkan al-Quran dan hadis.

Hadiah dalam kamus ertinya pemberian yang dibenarkan bertujuan kenang-kenangan, penghargaan dan penghormatan. ${ }^{20}$ Adapun hadiah dalam pengertian figh Islam hampir sama dengan hibah, iaitu pemberian sesuatu untuk memuliakan seseorang tanpa mengharap balasan. ${ }^{21}$ Akan tetapi menurut pandangan Sayid Sābiq, hadiah sebaik-baiknya orang yang diberi memberikan balasan setelah diberi hadiah. ${ }^{22}$ Hadiah yang dimaksudkan di sini supaya berbeza dengan hibah ialah pemberian sesuatu kepada orang lain dengan bermaksud sebagai kenang-kenangan, penghargaan atau penghormatan terhadap suatu prestasi.

Najm al-Dīn Aḥmad Ibn al-Rafî‘ah dalam kitabnya Kifāyah Rasūlullah $S A W$ fì Sharh al-Tanbīh yang dikutip oleh 'Abd Ghanī Ibn Isma'il dalam Tahqìq al-Qädiyah fì al-Farq bayna al-Rishwah wa al-Hadiyah, ia berkata, hadiah ialah jenis-jenis kebaikan (pemberian) yang mengandungi makna adanya pemindahan hak milik tanpa balasan, yang mana kebaikan itu dibawa ke tempat orang yang diberi sebagai bentuk penghormatan untuk memupuk silaturrahim. ${ }^{23}$ Tetapi jika tidak seperti itu, maka pemberian itu dinamakan sebagai hibah. Apabila kebaikan atau pemberian itu dimaksudkan semata-mata untuk mencari pahala dari Allah SWT dengan memberikan kepada orang yang memerlukan, maka perbuatan itu dinamakan sebagai sedekah. Maka, hadiah ialah bentuk pemberian kepada seseorang sebagai bentuk penghormatan dan memupuk persaudaraan dan kasih sayang.

\footnotetext{
20 Tim, Kamus Besar Bahasa Indonesia (Jakarta: Balai Pustaka, 1996), 333.

21 Sa'di Abū Jayb, al-Qamūs al-Fiqh (Beirūt: Dār al-Fikr, 1998), 367 dan 390.

22 Sayid Sābiq, Fiqh al-Sunnah, vol. 3 (Beirūt: Dār al-Fikr, 1983), 388.

23 Sayid Sābiq, Fiqh al-Sunnah, 80-81.
} 
Sedangkan rishwah ialah sesuatu yang diberikan kepada seseorang untuk menghidupkan kebatilan atau untuk menghancurkan kebenaran. Shaykh 'Abd al-'Azīz Ibn 'Abd Allāh Ibn Baz mendefinisikan rishwah dengan memberikan harta kepada seseorang sebagai pampasan pelaksanaan keperluan (tugas/ kewajipan) yang tugas itu harus dilaksanakan tanpa menunggu imbalan atau wang tip. ${ }^{24}$ Sedangkan mengikut terminologi fiqh, rishwah ialah segala sesuatu yang diberikan oleh seseorang kepada seorang hakim atau yang bukan hakim agar ia memutuskan suatu perkara untuk kepentingannya atau agar ia mengikuti kemahuannya. ${ }^{25}$ Oleh yang demikian, rishwah adalah merupakan amalan yang sangat merugikan baik kepada individu, masyarakat, dan negara. Bahkan kesan negatif yang ditimbulkan daripada perilaku rishwah tersebut begitu luas terhadap moral masyarakat (al-akhlāq al-karīmah), kehidupan bangsa dan negara.

Tujuan umum syariat Islam adalah membawa kemaslahatan manusia dalam kehidupan serta melenyapkan, menghapuskan, dan menolak bahaya ( mafsadah) yang akan menimpa mereka. Gratifikasi sebagaimana yang terdapat dalam penjelasan undang-undang semasa di Indonesia apabila ditinjau dari perspektif hukum Islam ianya termasuk amalan yang mempunyai mafsadah terhadap harta benda dan kemanusiaan. Dalam lembaran sejarah Islam, telah diberikan beberapa langkah pencegahan dan pembanterasan jenayah, yang mana langkah ini boleh diguna pakai dalam usaha solusi pencegahan dan pembasmian gratifikasi.

\section{SOLUSI GRATIFIKASI MENURUT ISLAM}

\section{Solusi Pencegahan Gratifikasi}

Langkah pencegahan (preventif) yang boleh diambil dari Hukum Islam dalam usaha mencegah daripada berlakunya amalan gratifikasi ialah seperti polisi-polisi yang sudah pernah dilakukan oleh Rasulullah SAW dan Khalifah 'Umar al-Khațtab pada masa pemerintahannya dalam menangani amalan yang mempunyai unsur-unsur gratifikasi atau yang tergolong dalam jenayah $t a$ ' $z \bar{\imath} r$ pada masa itu. Langkah-langkah itu penyelidik jelaskan sebagai berikut:

\footnotetext{
24 Abu Abdul Halim Ahmad. S, Suap Dampak dan Bahyanya Bagi Masyarakat (Jakarta: Pustaka Al-Kautsar, 1996), 20-21.

25 Muhammad Amīn Ibn 'Abidīn, Radd al-Mikhtar 'alā al-Dār al-Mukhtār Hasyiyāt Ibn 'Abidīn, vol. 7 (Beirūt: Dār al-Iḥyā', 1987), 5.
} 
a) Sistem penggajian yang layak. Pegawai Negeri atau Penyelenggara Negara sebagai pelayan masyarakat harus bekerja dengan sebaik-baiknya. Dan itu sukar berjalan dengan baik apabila gaji mereka tidak mencukupi. Para petugas negara tersebut tetaplah manusia biasa. Rasulullah SAW dalam hadis yang diriwayatkan Abū Dāwūd berkata, "barang siapa yang diserahi pekerjaan dalam keadaan tidak mempunyai rumah, akan disediakan rumah, jika belum beristeri hendaknya menikah, jika tidak mempunyai pembantu hendaknya ia mengambil pelayan, jika tidak mempunyai haiwan tunggangan (kenderaan) hendak diberi. Dan barang siapa mengambil selainnya, itulah kecurangan (ghalin)." Khalifah 'Umar memberi gaji yang cukup bagi kos hidup pegawai dan keluarganya. ${ }^{26}$ Oleh kerana itu, perlu ada usaha penyelidikan menyeluruh terhadap sistem penggajian dan tunjangan terhadap pegawai kerajaan dan penganjur negara di Aceh.

b) Mengisytiharkan kekayaan bagi para Pegawai Negeri atau Penyelenggara Negara. Orang yang melakukan gratifikasi tentu jumlah kekayaannya akan bertambah dengan cepat. Meskipun tidak selalu orang yang cepat kaya disebabkan oleh gratifikasi. Kekayaan petugas negara sesudah berkhidmat berbanding dengan kekayaan petugas negara sesuai dengan senarai kekayaan sebelum berkhidmat. Selisih lebih kekayaan itu, yang separuhnya dirampas, dan dimiliki oleh negara. ${ }^{27}$ Kebijaksanaan seperti itu dikenal dengan "ta'dibu al-muwadaf bi al-muqasamah fì al-amwāl”. Semasa menjadi khalifah, 'Umar mewajibkan Pegawai Negara untuk mendaftarkan harta kekayaannya, di mana 'Umar menghitung kekayaan para Pegawai Negara di awal dan di akhir tugasnya. Apabila terdapat kenaikan yang tidak wajar, mereka yang berkaitan akan diminta untuk membuktikan bahawa kekayaan yang dimiliki itu diperolehi dengan cara yang halal. Jika gagal, 'Umar memerintahkan mereka yang berkaitan untuk menyerahkan lebihan harta daripada jumlah yang sepatutnya kepada Bayt al-Māl. Cara inilah yang penyelidik sebut dengan kewajipan melaporkan atau mendaftarkan kekayaan bagi Pegawai Negeri atau Penyelenggara Negara. Cara yang dilakukan oleh 'Umar ini pula yang dikenal dengan pembuktian terbalik dalam Hukum Jenayah Islam.

c) Melaksanakan perintah Allah dengan menjauhkan diri daripada memakan sesuatu yang bukan haknya, sebagaimana yang termaktub dalam Surah alHasyr, ayat 7.

\footnotetext{
26 Al-Qāsimī, Nizām al-Hukmi fì al-Syarī'ah wa al-Tarikh (Beirūt: Dār al-Nafā'is, $1394 \mathrm{H} / 1974 \mathrm{M}), 520-522$.

27 Al-Qāsimī, Niẓām al-Hukmi, 522.
} 
d) Melakukan al-taftisī (kawalan) kepada Pegawai Negeri atau Penyelenggara Negara. Dalam Islam disebut dengan "al-taftisī șāḥib al-ummal” kepada bawahannya. ${ }^{28}$ "Rasulullah SAW melarang seorang petugas negara menerima pemberian (gratifikasi) dari rakyat. Beliau menjatuhi hukuman dalam bentuk teguran, dalam peristiwa Ibn al-Lutabiyah yang diangkat menjadi Pegawai Zakat dan menerima hadiah dari salah seorang anggota masyarakat yang telah diwajibkan ke atasnya zakat," sebagaimana yang sudah dijelaskan di atas. Dalam pada itu, masyarakat juga perlu dilibatkan dalam melakukan pengawasan, kerana masyarakat berperanan menyuburkan gratifikasi.

e) Pola hidup sederhana, sebagaimana yang sudah dianjurkan dalam Islam, perlu dilembagakan dalam suatu peraturan yang mantap, berwibawa dan efektif. Untuk mengamalkan "pola hidup sederhana", perlu adanya penghayatan dan pengamalan sifat qana'ah yang dianjurkan oleh ajaran tasawuf. Qana'ah bermaksud merasa cukup dengan apa yang ada serta tidak berhenti daripada berusaha. ${ }^{29}$ Tindakan-tindakan yang bersifat "operasi mental" dan latihan kesedaran individu tidak lain tidak bukan adalah untuk mewujudkan kakitangan kerajaan yang berakhlaq al-karimah (berbudi luhur). Oleh kerana itu, Pegawai Negeri, Penyelenggara Negara dan masyarakat keseluruhannya perlu dibina mentalnya dengan nilainilai luhur yang terkandung dalam ajaran tasawuf. Tasawuf bermaksud mensucikan hati daripada sifat-sifat kejiwaan yang tercela dan menghiasinya dengan sifat-sifat psikologi yang terpuji, dan diisi ke dalam jiwa, sifat-sifat psikologi yang unggul. Sifat mental hubb al-dunya (gila dunia), rakus, tamak, hubb al-jah wa al-riyāsah (gila pangkat dan jawatan), diusir keluar, dan diisi dengan mental qana'ah, zuhud (tiada kecintaan dunia), ikhlas, sabar, redha dan syukur.

\section{Solusi Pembanterasan Amalan Gratifikasi}

Selain usaha pencegahan gratifikasi, sewajarnya juga dilakukan tindakantindakan represif (pembanterasan) terhadapnya dengan memberikan hukuman jenayah yang berat. Apabila ditinjau dari sudut hukum Islam, maka gratifikasi sebagaimana yang digambarkan dalam undang-undang boleh dikategorikan di bawah jarimah al-ta 'zīr iaitu dihukum dengan hukuman yang sangat berat.

Adapun dari sudut pandang hukum Islam, terdapat enam langkah pembanterasan amalan gratifikasi yang perlu dilakukan, iaitu:

\footnotetext{
28 Al-Qāsimī, Niẓām al-Hukmi, 502-506.

29 HAMKA, Tasauf Modern (Jakarta: Pustaka Panjimas, 1987), 23.
} 


\section{a) Memaksimumkan Hukuman}

Dalam hukum Islam, terdapat dua asas utama yang menjadi sandaran dalam hukuman, iaitu ganti rugi/balasan (retribution) dan pengajaran (deterrence).

Di sebalik rasional retribusi dalam hukuman, terdapat dua hal secara bersamaan yang menjadi unsur utama yang perlu ada di dalamnya. Pertama, hukuman yang berat, dan yang kedua kemestian hukuman itu diberikan kepada pelaku perbuatan jenayah. Sedangkan tujuan utama pengajaran adalah untuk mencegah berulangnya perbuatan jenayah tersebut daripada berulang di kemudian hari. Pengajaran mempunyai dua kesan, iaitu internal dan general. Kesan internal ialah supaya pelakunya terhalang dan tidak mengulangi perbuatannya lagi. Manakala kesan general pula memberi pengajaran kepada masyarakat secara umum agar takut untuk melakukan perbuatan jenayah.

Oleh kerana pelaku jenayah gratifikasi di Aceh adalah tergolong di bawah jarimah ta'zìr, maka hakim yang menentukan hukumannya. Hakim boleh berijtihad dalam menentukan berat atau ringan hukumannya. Meskipun demikian, dalam menentukan hukuman terhadap pelaku gratifikasi, seorang hakim perlu merujuk kepada tujuan syara' dalam menetapkan hukuman, kemaslahatan masyarakat, situasi dan keadaan persekitaran, dan situasi serta keadaan pelaku, sehinggalah mereka sedar dan insaf daripada melakukan perbuatan gratifikasi dan hukuman itu bertindak sebagai preventif bagi orang lain.

Disebabkan hakim mempunyai kuasa untuk berijtihad dalam menentukan hukuman terhadap pelaku jenayah gratifikasi, maka hakim boleh merujuk atau menjadikan bahan pertimbangan bentuk-bentuk hukuman mengenai gratifikasi yang ada dalam hukum Islam. Misalnya, jika penyalahgunaan kuasa atau jawatan (khiyānah/ghulül), hukumannya adalah dengan membakar hartanya, memukul atau mengarak keliling pelakunya bahkan boleh sampai hukuman mati mandatori. Hukuman-hukuman tersebut harus disesuaikan dengan konteks perundangan semasa di Aceh. Membakar harta misalnya boleh disamakan dengan merampas harta daripada gratifikasi dan menjadikannya perbendaharaan negara. Mengarak keliling pelakunya boleh memasang namanama pelaku gratifikasi di media cetak mahupun elektronik supaya mereka merasa malu dan tidak berani lagi mengulangi perbuatannya. Bahkan sekiranya pegawai tersebut melakukan gratifikasi wang yang sangat banyak sehingga menyebabkan kehancuran negara dan rakyat ditimpa krisis dan bencana, maka hakim sewajarnya memberikan hukuman mati kepada pelaku tersebut. 


\section{b) Penegakan Hukum}

Dalam sejarah perundangan Islam, tertegaknya hukum (supreme of court) itu didokongi oleh beberapa faktor. Pertama, institusi peradilan yang bebas. Maksudnya kuasa kehakiman harus mempunyai kebebasan dari segala macam campur tangan kuasa eksekutif. Kedua, amanah. Maksudnya kuasa kehakiman merupakan amanah dari Allah SWT. ${ }^{30}$ Oleh kerana itu, sebelum membuat keputusan, hakim selalu berlindung dan mengharap redha Allah SWT agar hukum yang ditetapkan setimpal dengan perbuatan jenayah yang dilakukan.

Bagi membanteras gratifikasi, semestinya hukum harus ditegakkan. Hukum harus menjadi sandaran di negeri ini, institusi kehakiman perlu amanah dan bebas dari segala campur tangan sesiapa, sebagai benteng terakhir para pencari keadilan. Institusi kehakiman harus memberikan jaminan rasa adil bagi setiap warga tanpa prejudis. Jangan lagi ada ungkapan bahawa hukum menampakkan ketegasannya hanya terhadap orang-orang kecil, lemah, dan tidak punya akses. Sementara jika berhadapan dengan orang-orang 'kuat', mempunyai akses kuasa, mempunyai modal, maka hukum menjadi lunak dan bersahabat. Penegakan hukum harus adil tanpa prejudis, baik orang lemah, orang kuat, orang miskin, orang kaya, anak petani maupun anak pejabat. Kalau melakukan gratifikasi harus ditindak sesuai hukum yang berlaku. Rasulullah SAW telah memberi contoh bahawa beliau sendiri yang akan memotong tangan puteri yang paling dicintai, Fatimah sekiranya beliau mencuri. Mahkamah perlu mempunyai kewibawaan di depan para pencari keadilan, sehingga siapapun tidak akan cuba-cuba untuk menjatuhkan kewibawaan institusi peradilan.

Dalam hadis tentang petugas pemungut zakat yang menerima pemberian dari masyarakat, Rasulullah SAW sebagai pemimpin menunjukkan ketegasannya dalam menegakkan hukum dengan langsung menangani pelanggaran yang dilakukan oleh pejabat yang ditunjuknya. Rasulullah SAW tidak menunggu sehingga menjadi kes besar. Ini menunjukkan bahawa dalam pengendalian pelanggaran tidak ada konsep penangguhan. Bagi pelaku, pengendalian langsung terhadap kesalahan yang dilakukannya tentu saja akan memberi kesan pencegahan dan ada perasaan bahawa semua yang dilakukannya ternyata diawasi.

Di samping itu, Rasulullah SAW dengan sangat tegas menggambarkan tanggungjawab yang harus dipikul oleh petugas/pejabatyang mengatasnamakan jawatannya untuk mendapatkan hadiah atau pemberian. Walaupun tidak

30 Makhrus Munajat, 'Penegakan Supremasi Hukum dalam Sejarah Peradilan Islam,' dalam Asy-Syir 'ah, 8 (Yogyakarta: Fakultas Syari'ah UIN Sunan Kalijaga, 2001), 49-50. 
dijelaskan ancaman jenayah yang akan diterima oleh penerima gratifikasi dan pemberi gratifikasi, akan tetapi Rasul dengan tegas memerintahkan untuk mengembalikan kepada negara semua yang telah diterimanya yang dianggap sebagai hadiah untuknya.

\section{c) Perubahan dan Penambahbaikan Sistem}

Perubahan sistem baik sistem birokrasi pemerintahan mahupun sistem hukum perlu dilakukan. Sistem birokrasi di Aceh dan Indonesia pada umumnya dikenali rumit sehingga sukar dilakukan pengawasan, sehingga terjadinya gratifikasi dalam segala pengurusan misalnya di bahagian imigresen, lalu lintas, terjadinya gratifikasi pada penerimaan Pegawai Negeri Sivil, TNI/ Polri, dan sebagainya. Mengikut penyelidik penting difikirkan kecenderungan tuntutan global berupa tuntutan penswastaan penyelenggaraan kegiatan. Ada dua segi dari tuntutan penswastaan ini. Pertama, pengurusan semula yang bersifat tunggal oleh kerajaan, dibangunkan menjadi "free enterprise" bagi pihak swasta. Kedua, polisi penswastaan perlu difahami sebagai usaha melepas monopoli penyelenggaraan dan kawalan oleh kerajaan selama ini justeru menyebabkan tumbuh suburnya amalan gratifikasi.

Berkaitan sistem, penting juga diperhatikan tentang sistem negara yang berasaskan demokrasi. Dalam sistem demokrasi, amalan gratifikasi tidak mudah untuk dihapuskan. Terdapat tiga faktor penyebab tidak dapat diselesaikan gratifikasi secara menyeluruh apabila sistem negara berdemokrasi tanpa batasan seperti di Indonesia. Pertama, mahalnya kos atau modal yang diperlukan untuk menjadi Pegawai Negeri atau Penyelenggara Negara. Misalnya untuk menjadi Penyelenggara Negara sebagai anggota legislatif (parlimen) dan eksekutif (pemerintahan). Bagi mencalonkan diri sebagai wakil rakyat di parlimen dan sebagai eksekutif (gabenor, bupati, walikota umpamanya), ianya memerlukan dana yang sangat besar. Dana tersebut boleh jadi digunakan untuk kos kempen awal, politik wang, dan sebagainya. Sangat mustahil dana tersebut semuanya murni bersumberkan daripada harta peribadi. Tentunya dana yang begitu besar dibantu oleh pemodal-pemodal lain. Hal inilah yang pada akhirnya adanya perjanjian-perjanjian antara Penyelenggara Negara dengan pemodal tadi. Tambahan lagi, Penyelenggara Negara tersebut akan berupaya keras untuk mengembalikan modal yang cukup besar yang sudah dikeluarkan ketika pencalonan dulu, sehingga akibatnya terbuka dengan cepat penerimaan gratifikasi. Sistem negara berdemokrasi semakin kelihatan dan dirasakan betapa besarnya kesan negatif yang ditimbulkannya.

Di dalam Islam, sistem negara berasaskan Islam tidak memerlukan kos yang mahal dalam pemilihan pemimpin (Penyelenggara Negara). Ini disebabkan 
oleh singkatnya waktu yang diperlukan dalam pemilihan Penyelenggara Negara dalam Islam iaitu hanya memerlukan tempoh beberapa hari sahaja. Hal ini berdasarkan kepada tempoh peralihan antara kepemimpinan Rasulullah SAW kepada Khalifah 'Umar al-Khattab. Walaupun demikian, pemimpin yang dicalonkan tetap harus dipilih, pemimpin yang memenuhi syarat untuk menjadi seorang pemimpin, dan dapat dipastikan ia memahami bahawa kelak akan dipertanggungjawabkan di hadapan Allah SWT selama mana kepemimpinannya.

Demikian juga sistem hukum di Aceh (Indonesia) yang masih berbau penjajah perlu segera diselesaikan secara keseluruhan. Sistem hukum yang berlaku adalah sistem hukum Belanda yang tergolong dalam sistem Eropah Continental yang lebih menitikberatkan kepada formal-prosedur dan cenderung kepada ketidak adilan. Paradigma rechstaat yang formal-prosedural seperti ini sebaiknya digantikan dengan paradigma the rule of law yang mementingkan keadilan. Terdapat dua sebab utama kenapa sistem hukum perlu ada perubahan atau penambahbaikan jika gratifikasi di Aceh dapat dibasmi. Pertama, alasan normatif, iaitu sistem hukum sekarang pada dasarnya tidak berlandaskan Syariat Islam. Kedua, alasan empiris, iaitu sistem hukum yang kini telah terbukti gagal melakukan penegakan hukum serta pembasmian gratifikasi.

Dalam Islam, hukum bersifat pencegahan dan penebus. Kewujudan Hukum Islam sebagai pencegah, kerana mampu mencegah manusia dari perbuatan dosa dan tindak pelanggaran serta menimbulkan kesan penghalang bagi pelakunya dan kesan pengajaran terhadap yang melihatnya. Keberadaannya sebagai penebus, kerana Hukum Islam dapat menebus hukuman di akhirat.

Dalam hal pembuktian, dalam sistem Eropah Continental, kaedah pembuktian yang dipakai sebagai contoh adalah barangsiapa yang menuduh seseorang melakukan gratifikasi maka si penuduh tersebut harus boleh memberikan bukti-bukti lengkap atas dakwaan beliau, tidak peduli apakah kekayaan yang dimiliki si tertuduh sesuai atau tidak dengan pendapatannya. Kalau tidak, maka dia dianggap melakukan pencemaran nama baik dan boleh dihukum kerananya. Sistem Hukum Islam akan dikuatkuasakan sistem 'pembuktian terbalik' terutama dalam kes gratifikasi sangat penting dan kalau memungkinkan boleh segera dilaksanakan sehingga apabila ada orang yang dituduh pelaku gratifikasi maka si tertuduh lah yang harus membuktikan bahawa dia tidak melakukan gratifikasi. Namun demikian, sistem seperti ini perlu diberikan garis panduan agar tidak sewenang-wenangnya setiap orang menuduh orang lain melakukan konspirasi gratifikasi. 


\section{d) Memantapkan Pemahaman Hukum}

Pemahaman hukum agama yang kurang tentang gratifikasi dalam kalangan masyarakat menjadi salah satu daripada penyebab berlakunya gratifikasi. Dengan masih banyaknya anggapan masyarakat mengenai pemberian kepada Pegawai Negeri atau Penyelenggara Negara sebagai bahagian dari hadiah yang dibolehkan dan dianjurkan menandakan bahawa pemahaman keagamaan masyarakat tentang hukum masih kurang. Untuk itu diperlukan sosialisasi atau berhubung pembinaan khusus berkaitan dengan gratifikasi ini dengan melakukan pendekatan Hukum Islam. Dengan peningkatan kefahaman masyarakat mengenai gratifikasi dalam tinjauan Islam diharapkan munculnya kesedaran dalam dirinya untuk meninggalkan amalan gratifikasi. Kerana dalam Islam, gratifikasi adalah amalan yang sangat dibenci kerana bertentangan dengan naș, baik secara langsung mahupun tidak langsung.

\section{e) Keteladanan Pemimpin}

Pembanterasan gratifikasi akan berjaya apabila pemimpin, terutamanya pemimpin tertinggi dalam sesebuah negara bersih dari amalan gratifikasi dan amalan tercela lainnya. Dengan sifat taqwa yang dimilikinya, seorang pemimpin melaksanakan tugas dengan penuh amanah. Dengan taqwa pula, ia takut melakukan penyelewengan. Kerana dalam hatinya tertanam kuat keyakinan meski boleh berbuat curang dan menutupi kejahatannya, Allah SWT pasti melihat semuanya dan di akhirat pasti akan dipertanggungjawabkan. Disinilah diperlukan keteladanan dari para pemimpin itu untuk diteladani oleh rakyatnya. Hal ini sebagaimana yang dicontohkan oleh Rasulullah SAW dan para sahabatnya. Khalifah 'Umar sebagai contoh, ia memberikan teladan dengan merampas sendiri seekor unta milik puteranya, 'Abd Allāh bin 'Umar, kerana kedapatan digembalakan di padang rumput milik Bayt al-Māl sebagai bentuk penyalahgunaan fasilitas negara.

\section{f) Revolusi Kebudayaan (mental/akhlak)}

Gratifikasi layaknya sudah menjadi budaya setempat masyarakat Indonesia. Hampir setiap aktiviti sedikit banyak berkaitan dengan gratifikasi. Dalam pengurusan perkhidmatan public yang menjadi keperluan rakyat miskin pun turut berlaku. Paradigma birokrasi di negeri ini masih berkiblat pada paradigma lama iaitu paradigma 'kuasa' bukan paradigma 'perkhidmatan' sehingga segala sesuatunya pemegang kuasa yang menetapkan. Jika ingin mendapatklan perlindungan, pekerjaan, projek, dan lain sebagainya harus memberikan 'sesuatu' berupa gratifikasi kepada penguasa yang melayani. 
Ketika gratifikasi sudah menjadi budaya, tidak ada jalan lain yang boleh diharapkan untuk membanteras gratifikasi melainkan dengan melakukan revolusi kebudayaan. Revolusi kebudayaan adalah mengubah secara fundamental tata pikir, tata kesedaran, dan tata perilaku sebagai akar budaya politiknya. Jadi untuk membanteras gratifikasi harus ada perubahan secara fundamental tata fikir, tata kesedaran, dan tata perilaku seluruh elemen negeri bermula dari pejabat yang tertinggi hingga rakyat jelata.

Revolusi kebudayaan yang pernah berlaku dalam sejarah perjalanan hidup Rasulullah SAW. Nabi Muhammad SAW telah mengubah akar budaya masyarakatnya, melalui rombakan sistem ketuhanan, dari mempertuhankan berhala sebagai manifestasi simbolik kekayaan dan kekuasaan yang disakralkan dan dicipta manusia sendiri, kemudian diubah hanya mempertuhankan Allah SWT yang mencipta manusia. Tuhan yang mencipta, bukan yang diciptakan. Untuk kepentingan jangka panjang, starting point yang paling penting dan strategik dalam melahirkan anak bangsa yang mempunyai tata pikir, tata kesedaran, dan tata kelakuan yang bebas gratifikasi adalah paradigma pendidikan. Paradigma pendidikan ke depan harus boleh mewujudkan anak bangsa yang nantinya boleh hidup jauh dari amalan gratifikasi yang dikategorikan jenayah ini. Dari awal sudah harus ditanamkan bahawa amalan gratifikasi adalah perbuatan haram yang harus dijauhi dan dimusuhi. Oleh kerana itu, ajaran-ajaran agama dan ajaran anti gratifikasi perlu masuk dalam kurikulum pendidikan di Aceh.

Agama Islam yang berasaskan kepada al-Quran dan sunnah membawa misi perbaikan moral, kerana inti ajaran al-Quran dan sunnah adalah perbaikan moral. Inti ajaran Islam ialah moral yang bertumpu pada hubungan manusia dengan Tuhan dan hubungan manusia dengan manusia lain. Inti ajaran Islam tentang moral tersebut selain untuk difahami dan dihayati, namun yang terpenting lagi diamalkan dengan bersungguh-sungguh. Untuk itu, revolusi kebudayaan (mental/akhlak) yang mulia harus disokong oleh semua pihak. Usaha ini berkaitan dengan usaha mengatasi terjadinya gratifikasi yang disebabkan rendahnya kualiti sikap mental dan akhlak yang dianuti oleh masyarakat.

Secara jelas, banyak nilai-nilai Islam yang mengajarkan tentang anti gratifikasi. Diantaranya adalah kejujuran (șiddiq), kepercayaan (al-amānah), kesederhanaan, kerja keras, disiplin, tanggung jawab, mandiri, adil (al'adālah), peduli, dan lain-lain. Semua moral yang ada dalam Islam tersebut banyak diselewengkan dalam amalan gratifikasi yang berlaku di Indonesia. Untuk itu, pemulihan dan rekontruksi kebudayaan mental masyarakat 
Indonesia sesuai dengan tuntunan Islam sangat penting untuk dilakukan dalam rangka penyelesaian mencegah dan membanteras amalan gratifikasi.

\section{PENUTUP}

Dari huraian tentang gratifikasi dalam perspektif hukum positif di Indonesia dapat disimpulkan bahwa, berkenaan dengan gratifikasi sudah diatur dalam Undang-undang Nombor 20 Tahun 2001 tentang Pemberantasan Tindak Pidana Korupsi. Gratifikasi menurut undang-undang semasa mempunyai makna yang luas, iaitu segala bentuk pemberian kepada Pegawai Negeri atau Penyelenggara Negara.

Gratifikasi mengikut undang-undang membawa makna positif dan boleh juga bermakna negatif. Gratifikasi yang dibolehkan oleh undang-undang adalah pemberian yang dilakukan dengan niat yang tulus dari seseorang kepada Pegawai Negeri atau Penyelenggara Negara tanpa tanpa mengharapkan balasan apa-apa. Sedangkan gratifikasi yang dilarang dalam undang-undang adalah perbuatan penerimaan gratifikasi oleh Pegawai Negeri atau Penyelenggara Negara apabila pemberian tersebut dilakukan kerana berhubungan dengan jawatannya, dan berlawanan dengan kewajipan atau tugasnya. Maka dari itu, undang-undang semasa di Indonesia tidak melarang semua bentuk pemberian (gratifikasi) yang terjadi dalam masyarakat.

Islam melarang gratifikasi sebagaimana yang dimaksudkan dalam undangundang semasa di Indonesia. Selain itu, amalan gratifikasi dapat diatasi sama ada melalui pencegahan atau pun tindakan. Jadi langkah-langkah yang boleh ditempuh sesuai dengan Hukum Islam supaya gratifikasi tidak dilakukan lagi oleh masyarakat Indonesia ialah sistem gaji yang layak, wajib daftar kekayaan bagi para pegawai, melaksanakan perintah Allah menjauhi memakan sesuatu yang bukan haknya, melakukan "al-taftiš̄" (kawalan) kepada Pegawai Negeri atau Penyelenggara Negara, memaksimumkan hukuman, penegakan supremasi hukum, perubahan dan pembaikan sistem, memantapkan pemahaman hukum, keteladanan pemimpin, dan revolusi kebudayaan (mental/akhlak). Jika langkah-langkah ini boleh dijalankan dengan sebenar-benarnya. InsyaAllah amalan jenayah gratifikasi akan jauh dari segala aktiviti seharian masyarakat Indonesia.

\section{RUJUKAN}

Abu Abdul Halim Ahmad. S, Suap Dampak dan Bahyanya Bagi Masyarakat (Jakarta: Pustaka al-Kautsar, 1996). 
Al-Qāṣimī, Niẓām al-Hukm fì al-Syarī'ah wa al-Tarikh (Beirūt: Dār al-Nafā' is, 1394 H/1974 M).

Doni Muhardiansyah et al., Buku Saku Memahami Gratifikasi (Jakarta: Komisi Pemberantasan Korupsi Republik Indonesia, 2010).

Eddy OS Hiareij, 'Memahami Gratifikasi,' http://nasional.kompas.com/ $\mathrm{read} / 2011 / 06 / 13 / 03392292 /$ memahami.gratifikasi, diakses pada 13 Julai 2011.

HAMKA, Tasauf Modern (Jakarta: Pustaka Panjimas, 1987).

Makhrus Munajat, 'Penegakan Supremasi Hukum dalam Sejarah Peradilan Islam,' dalam Asy-Syir 'ah (Yogyakarta: Fakultas Syari'ah UIN Sunan Kalijaga, 2001).

Muhammad Amīn Ibn 'Ābidīn, Radd al-Mikhtar 'alā al-Dār al-Mukhtār Hashiyāt Ibn 'Ābidīn (Beirūt: Dār al-Iḥyā', 1987).

Penulis tidak diketahui, 'Abdullah Puteh,'Anti-Corruption Clearing House $(A C C H)$, http://acch.kpk.go.id/abdullah-puteh, diakses pada 7 April 2015.

Penulis tidak diketahui, 'Angelina Patricia Pingkan Sondakh,' Anti-Corruption Clearing House (ACCH), http://acch.kpk.go.id/angelina-patriciapingkan-sondakh, diakses pada 7 April 2015.

Penulis tidak diketahui, 'Gratifikasi Berdasarkan Status Kepemilikan,' AntiCorruption Clearing House (ACCH), http://acch.kpk.go.id/gratifikasiberdasarkan-status-kepemilikan, diakses pada 6 April 2015.

Penulis tidak diketahui, 'Miranda Saraway Goeltom,' Anti-Corruption Clearing House (ACCH), http://acch.kpk.go.id/miranda-swaray-goeltom, diakses pada 7 April 2015.

Penulis tidak diketahui, 'Tentang ACCH,'Anti-Corruption Clearing House (ACCH), http://acch.kpk.go.id/tentang-acch, 6 April 2015.

Sa'di Abū Jayb, al-Qamūs al-Fiqh (Beirūt: Dār al-Fikr, 1998).

Sayid Sābiq, Fiqh al-Sunnah (Beirūt: Dār al-Fikr, 1983).

Tanti Yuniar, Kamus Lengkap Bahasa Indonesia (Jakarta: Agung Media Mulia, t.t.).

Tim, Kamus Besar Bahasa Indonesia (Jakarta: Balai Pustaka, 1996).

\section{Statut}

Undang-undang Nombor 31 Tahun 1999 juncto (pindaan) Undang-undang Nombor 20 Tahun 2001 tentang Pemberantasan Tindak Pidana Korupsi.

Undang-undang Nombor 5 Tahun 2014 tentang Aparatur Sipil Negara. 
Jurnal Syariah, Jil. 24, Bil. 2 (2016) 179-206 